\title{
Oude en nieuwe kopzorgen
}

Citation for published version (APA):

Wilmink, J. T. (1992). Oude en nieuwe kopzorgen. Datawyse / Universitaire Pers Maastricht. https://doi.org/10.26481/spe.19920619jw

Document status and date:

Published: 19/06/1992

DOI:

10.26481/spe.19920619jw

Document Version:

Publisher's PDF, also known as Version of record

\section{Please check the document version of this publication:}

- A submitted manuscript is the version of the article upon submission and before peer-review. There can be important differences between the submitted version and the official published version of record.

People interested in the research are advised to contact the author for the final version of the publication, or visit the DOI to the publisher's website.

- The final author version and the galley proof are versions of the publication after peer review.

- The final published version features the final layout of the paper including the volume, issue and page numbers.

Link to publication

\footnotetext{
General rights rights.

- You may freely distribute the URL identifying the publication in the public portal. please follow below link for the End User Agreement:

www.umlib.nl/taverne-license

Take down policy

If you believe that this document breaches copyright please contact us at:

repository@maastrichtuniversity.nl

providing details and we will investigate your claim.
}

Copyright and moral rights for the publications made accessible in the public portal are retained by the authors and/or other copyright owners and it is a condition of accessing publications that users recognise and abide by the legal requirements associated with these

- Users may download and print one copy of any publication from the public portal for the purpose of private study or research.

- You may not further distribute the material or use it for any profit-making activity or commercial gain

If the publication is distributed under the terms of Article $25 \mathrm{fa}$ of the Dutch Copyright Act, indicated by the "Taverne" license above, 


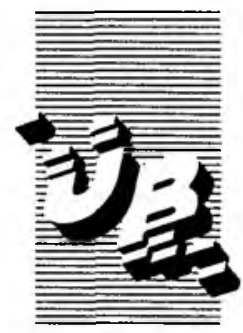

De uitleentermijn verstrijkt op:

\section{O $O$ SEP. 1992 \\ -6 HEI 19S?}

Rijksuniversiteit Limburg

Postbus 616

6200 MD Maastricht

Gelieve deze publicatie tijdig te retourneren of (telefonisch) verlenging van de uitleentermijn aan te vragen.

BIBLIOTHEEK RU LIMBURG 
Oude en nieuwe kopzorgen 
Omslagillustratie:

Compositie van Inca schedel met trepanatie-opening (Department of History of Medicine, University of Kansas) en 3-D MRI reformatie van schedel (Picker International) 


\title{
Oude en nieuwe kopzorgen
}

\author{
REDE \\ uitgesproken bij de aanvaarding van het ambt van \\ bijzonder hoogleraar in de neuroradiologie \\ aan de Rijksuniversiteit Limburg \\ op vrijdag 19 juni 1992 \\ door
}

DR. J.T. WILMINK

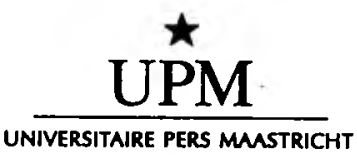


og5214917

Bollotheok

M.U. Limbers 
Mijnheer de Rector Magnificus, Zeer gewaardeerde toehoorders,

Ik wil het vanmiddag met $\mathbf{u}$ hebben over ontwikkelingen in de neuroradiologie, in het bijzonder die, die zich hebben voorgedaan sinds ik in het vak werkzaam ben. In deze periode heeft de beeldvormende techniek zich ontwikkeld op een wijze die haar weerga niet kent, en ik prijs me dan ook gelukkig zo'n uitermate boeiende periode als neuroradioloog meegemaakt te hebben en nog steeds mee te maken.

Zoals wel vaker gebeurt bij dit soort gelegenheden wil ik dus een terugblik geven, een overzicht van wat bereikt is en een poging doen om datgene dat tot stand is gekomen in een perspectief te plaatsen.

Het verhaal zal niet uitsluitend rooskleurig zijn. Ten eerste zijn in financieel opzicht in ons gezondheidssysteem de grenzen aan de groei zichtbaar. Zeer grote investeringen in moderne hulpmiddelen leiden tot betere, vlottere en vooral meer patiëntvriendelijke methoden voor diagnostiek en behandeling. Het meetbaar effect van dergelijke investeringen is echter verhoudingsgewijs veel geringer dan in een vroegere periode werd bereikt. Maatregelen als het aanleggen van riolering en de vaccinatie-programma's hadden bijvoorbeeld een veel ingrijpender effect op de gemiddelde levensduur. In dit opzicht zou men dus kunnen spreken van de wet van verminderende meeropbrengst. Wie kennis neemt van de dagbladpers zal duidelijk zijn geworden dat er een grens lijkt te zijn aan hetgeen men bereid is te investeren in onze getechnologiseerde vorm van gezondheidszorg.

Behalve deze financiële barrière stuiten wij ook op een ander probleem, dat juist het gevolg is van de sublieme ontwikkeling van beeldvormende technieken. De anatomische detailtekening in moderne digitale afbeeldingen is zodanig dat zij 
in vele gevallen kan wedijveren met de klassieke preparaten in anatomische tekstboeken. Naarmate wij meer ervaring krijgen met het bestuderen van de levende anatomie, vervaagt steeds meer het onderscheid tussen wat wij beschouwen als de normale anatomische vormgeving enerzijds en de vormveranderingen die worden geassocieerd met het ontstaan van ziekteverschijnselen anderzijds. Hierop zal ik later uitvoeriger ingaan.

Tenslotte is door de technologische revolutie van de afgelopen twee decennia niet alleen de werkwijze, maar ook de rol van de neuroradioloog, zoals die door hemzelf en door anderen wordt gezien, aan verandering onderhevig. Ook hieraan wil ik straks nog enkele woorden wijden.

\section{Historische ontwikkelingen}

Vanaf de oorlog is er op radiologisch terrein een zekere wisselwerking geweest tussen Groningen en Maastricht. De Maastrichtse radioloog Van der Plaats toonde zich in de vroege vijftiger jaren zijn tijd ver vooruit: hij combineerde zijn werkzaamheden in Maastricht met een deeltijdbaan van twee dagen per week als hoogleraar radiologie in Groningen. De assistent in opleiding Penning werd in 1956 naar Groningen gedetacheerd, aanvankelijk in het Radiologisch Instituut. Van hieruit stapte hij enkele jaren later over naar de neurochirurgische kliniek van Lenshoek, om daar de neuroradiologie te gaan bedrijven. Voor Nederland was dit een unieke situatie omdat tot voorheen de algemeen radioloog zich in het geheel niet bezig hield met de neuroradiologie. Penning ontpopte zich als een begaafd neuroradioloog en onderzoeker en werd in 1964 benoemd tot hoogleraar in dit vakgebied, waarmee de eerste leerstoel neuroradiologie in Nederland een feit was. Ik heb de eer en het genoegen gehad vele jaren 
met Lourens Penning samen te werken en dank aan deze samenwerking een belangrijk deel van mijn wetenschappelijke vorming. $\mathrm{Nu}$ is de leerstoel neuroradiologie als het ware van Groningen met mij naar Maastricht verhuisd, een nieuw hoofdstuk in deze "tale of two cities".

Reeds tijdens mijn medische studie in Groningen was mij opgevallen dat grote aantallen Limburgers, veelal medische studenten, zich in Groningen zeer wel thuis voelden, en ik heb goede herinneringen aan die keren dat ik in het begin van de zestiger jaren, in gezelschap van mijn Limburgse jaargenoten liftend naar Maastricht ben gereisd. Kennelijk vormen Maastricht en Groningen een voorbeeld van twee steden die alleen in geografisch opzicht elkanders tegenpool zijn.

Maar laat ik terugkeren naar de geschiedenis van de neuroradiologie, het vakgebied waarin ik in 1976, na een voltooide neurologische opleiding, min of meer bij toeval terecht $\mathrm{kwam}$. Weliswaar had op dat tijdstip de mens reeds geruime tijd eerder zijn eerste voetafdruk op de maan achtergelaten, toch onderscheidden de gangbare neuroradiologische technieken zich door een zekere eenvoud. Aangezien een conventionele röntgenopname onvoldoende gevoeligheid bezit om de weefsels binnen de schedel en het wervelkanaal zichtbaar te maken (hersenen en ruggemerg, zenuwvezels, bloedvaten), was het nodig om kunstmatige contrastverschillen tot stand te brengen. In de hersenen bevinden zich met vloeistof gevulde holle organen zoals hersenkamers en bloedvaten. Door nu de in deze organen aanwezige vloeistof (hersenvocht en bloed) te vervangen door radiologische contrastmiddelen, was het mogelijk een indruk te verkrijgen over de vorm en ligging van deze organen, en hieruit weer een conclusie te trekken over de toestand van de hersenen. Het 
verrichten van een dergelijk contrastonderzoek was voor de onderzoeker een kunst op zich en voor de patiënt zelden een pretje. Zo werd de halsslagader na plaatselijke verdoving van de huid en de omliggende weefsels met een naald aangeprikt, waarna een jodiumhoudende contrastvloeistof werd ingespoten om zodoende de hersenbloedvaten op de foto zichtbaar te maken. Een tweede veel toegepast onderzoek bestond hieruit dat via een punctie laag in de rug een hoeveelheid van het in het wervelkanaal aanwezige hersenvloeistof werd afgetapt en vervangen door een ongeveer gelijke hoeveelheid lucht. De ingespoten lucht vond haar weg naar de intracraniële ruimte en verzamelde zich in de hersenkamers, diep in de hersenen gelegen, maar ook in de liquorruimten rond de hersenen. De aanwezige luchtpartijen werden als negatieve uitsparingen zichtbaar op de röntgenfoto. Ze zorgden evenwel ook voor forse hoofdpijnklachten en andere bijverschijnselen bij de patiënt.

Zoals reeds is gezegd werd in het begin deze beeldvormende diagnostiek van het zenuwstelsel bedreven door niet-radiologen; vooral neurologen en neurochirurgen. In navolging van het Groningse voorbeeld ontwikkelden zich evenwel in de loop van de jaren in de academische ziekenhuizen aparte afdelingen neuroradiologie, vaak organisatorisch ondergebracht bij de afdeling neurochirurgie, maar bemand door radiologen, dikwijls met een neurologische of neurochirurgische vooropleiding.

Bij mijn aantreden in 1976 kondigden zich nieuwe ontwikkelingen aan. Sinds een aantal jaren had men de techniek van de isotopenscintigrafie ter beschikking, waarbij een licht-radioactieve substantie in een ader werd ingespoten. Dit radiofarmacon verdeelde zich dan volgens bepaalde patronen binnen en buiten de hersenen en afwijkende patronen konden worden geregistreerd, hetzij digitaal met behulp van een 
zogenaamde scanner, hetzij analoog met de gamma camera. Een belangrijk nadeel van de methode vormde de gebrekkige scherpte van de gemaakte opnamen en de onmogelijkheid om het hersenweefsel zelf in beeld te brengen.

De volgende en meest baanbrekende digitale techniek die zich aandiende was de computertomografie of CT. De eerste patiënt die in 1971 met deze methode werd onderzocht was een 41-jarige vrouw met een frontale hersentumor. In 1972 werd de nieuwe ontwikkeling wereldkundig gemaakt, en in de tweede helft van de zeventiger jaren werden in meerdere Nederlandse centra CT-scanners geplaatst, waarbij het Academisch Ziekenhuis Groningen in 1977 aan de beurt was.

De computertomografie had vérstrekkende gevolgen voor de neuroradiologie. De techniek van het cerebrale luchtonderzoek was met één slag obsoleet; zo vervangt de ene radiologische methode de andere. Zonder ingrepen aan de patiënt was het mogelijk om voor het eerst de inwendige en uitwendige vorm van de hersenen te bestuderen, en zelfs een onderscheid te maken tussen de witte stof en de grijze stof. In bepaalde gevallen kon de diagnostiek verder worden verfijnd door een injectie in de ader van een röntgencontrastmiddel, veel minder onaangenaam voor de patiënt dan inspuiting in een slagader. De CT techniek werd steeds verder geperfectioneerd, dunnere sneden door het lichaam werden mogelijk en verbeterde computerreconstructietechnieken maakten een kortere onderzoekstijd en een hogere anatomische resolutie mogelijk. CT werd behalve voor onderzoek van de schedelinhoud ook steeds vaker toegepast op een ander belangstellingsgebied van de neuroradioloog: de wervelkolom. Daarnaast werden ook bijv. de borst- en buikorganen voor deze onderzoeksmethode toegankelijk.

Door de komst van de computertomografie nam cerebrale angiografie in betekenis af; de directe afbeelding van het 
normale en abnormale hersenweefsel maakten het overbodig om een indirecte diagnose te stellen op grond van de effecten van pathologische processen op de bloedvaten van de hersenen. De angiografie bleef haar betekenis houden voor aandoeningen van de vaten zelf, zoals arteriosclerotische vernauwingen, vaatmisvormingen zoals een aneurysma en de betrekkelijk zeldzame vaatontstekingen. De voor de patiënt onaangename directe carotispunctie werd vervangen door de zogenaamde Seldinger techniek, waarbij het contrastmiddel in de hersenvaten werd ingespoten via een catheter, een dun soepel kunststof slangetje dat werd ingebracht via de liesslagader. Ook in het beeldvormende deel van de angiografie deed de digitale techniek zijn intrede. Reeds voor de oorlog was door de Nederlandse neuroradioloog Ziedses des Plantes de fotografische subtractie techniek bij afbeelding van de bloedvaten ontwikkeld en toegepast. Met behulp van deze methode konden hinderlijke overprojecties van skeletstructuren over en tussen de bloedvaten worden gemaskeerd. Toepassing van de rekenkracht van de computer in dit gebied gaf een veel snellere bewerking van het beeldmateriaal met subtractiebeelden van een zodanige kwaliteit dat met een veel geringer contrastaanbod kon worden volstaan. Het gebruik van een geringere hoeveelheid contrast, minder krachtig ingespoten en vaak in een minder gevoelige lokatie binnen het vaatstelsel, betekent een aanzienlijke toename van de veiligheid van de methode en ook weer een winst aan patiëntengemak:

De jongste tak aan de boom van de beeldvormende diagnostiek heet kernspintomografie of magnetische resonantie beeldvorming, in de wandelgangen MRI genoemd, een afkorting van magnetic resonance imaging. Alhoewel ook deze afbeeldingsmethode een lange voorgeschiedenis heeft, werd 
de klinische betekenis pas in de eerste helft van de tachtiger jaren duidelijk.

Door een grotendeels uit water bestaand voorwerp zoals het menselijk lichaam in een krachtig magneetveld te plaatsen, treedt het verschijnsel op dat de waterstofkernen of protonen zich parallel of anti-parallel aan dit magneetveld richten. Indien men nu van buitenaf energie aan deze protonen toedient door middel van een ingestraald radiosignaal met een bepaalde frequentie kan men de protonen ertoe brengen om zelf als miniscule radiozendertjes te gaan fungeren. Dit verschijnsel is wel vergeleken met het resoneren of meetrillen van een stemvork met geluid dat men op dezelfde toonhoogte naast de stemvork opwekt. De frequentie van zowel het ingestraalde als het uitgezonden signaal is bij MRI afhankelijk van de sterkte van het magneetveld. Wanneer nu het uitwendige radiosignaal wordt uitgeschakeld, dooft ook het door de protonen uitgezonden signaal geleidelijk uit met een snelheid die afhankelijk is van de eigenschappen van het weefsel. Door met verschillende combinaties van uitwendige radiopulsen de protonen te laten resoneren en op verschillende tijdstippen de uitgezonden signalen te registreren, kan een schat aan informatie worden verzameld over verschillende eigenschappen van het te onderzoeken weefsel. De anatomie van de hersenen en ook van andere organen is buitengewoon fraai en in alle gewenste vlakken af te beelden, en verschillen in samenstelling van het weefsel zijn op zeer gevoelige wijze te detecteren. In deze beide opzichten is MRI duidelijk superieur aan CT. Behalve voor het vervaardigen van anatomische afbeeldingen is de methode ook geschikt om dynamische processen zoals vloeistofbewegingen te detecteren en te kwantificeren, waarbij het zowel kan gaan om de snellere bewegingen, zoals de bloedstromen en de hieruit afgeleide liquorbewegingen, als om de veel tragere diffusie- 
bewegingen op cellulair niveau. Spectroscopische analyse van diverse normale en abnormale weefseltypen is mogelijk met behulp van magnetische resonantie, en wordt in meerdere onderzoekscentra uitgevoerd.

MRI heeft zich in de loop van de tachtiger jaren gevestigd als nieuwe beeldvormende methode die bij uitstek geschikt is voor onderzoek van het zenuwstelsel en in toenemende mate ook voor andere organen. Evenals bij CT het geval was, is ook de introduktie van $\mathrm{MRI}$ in ons land veel trager verlopen dan in de omringende landen, tengevolge van een restrictief overheidsbeleid.

\section{Vooruitgang en haar keerzijde}

De winst van een geavanceerde afbeeldingsmethode als MRI, is tweeledig.

Ten eerste is hier reeds genoemd het voordeel van de geringere invasiviteit. Diagnostiek, en zeker neuroradiologische diagnostiek, is thans in vergelijking met 1976 een voor de patiënt veel minder belastende en riskante zaak geworden. De patiënt neemt plaats in de scanner en na enkele minuten tot ruim een half uur is het onderzoek voltooid. In enkele gevallen wordt een contrastmiddel intraveneus toegediend, sommige patiënten klagen over een gevoel van claustrofobie tengevolge van de beperkte ruimte binnen een MRI scanner. Evenals CT het cerebrale luchtonderzoek heeft verdrongen zo heeft MRI de myelografie (contrastafbeelding van het ruggemerg) al grotendeels overbodig gemaakt. Hetzelfde zal binnenkort geschieden met de caudografie (contrastafbeelding van de zenuwwortels in de lage rug), en, op iets langere termijn, met een groot deel van angiografie. Zelfs de computertomografie wordt bedreigd door de veel betere beelden die worden verkregen met behulp van MRI, met meer gun- 
stige afbeeldingsvlakken en minder artefactvorming, en zonder dat er gebruik gemaakt wordt van ioniserende straling. Het tweede winstpunt van MRI is gelegen in het kostenaspect. Zeker, MRI apparatuur is uitermate prijzig. Afhankelijk van de veldsterkte van de magneet en de bijgeleverde randapparatuur zal de aanschafprijs van een MRI scanner tussen de 2 en de 6 miljoen gulden liggen. Er vindt dus een omvangrijke jaarlijkse afschrijving plaats en het apparaat moet worden bediend door gespecialiseerd personeel, terwijl er daarnaast natuurlijk ook nog sprake is van vaste en variabele apparatuurgebonden bedrijfsonkosten.

In een recente studie naar de kosten van MRI berekende Ziedses des Plantes jr. dat de uurprijs van een "gemiddeld" MRI systeem iets hoger lag dan die van een vergelijkbare CT scanner. Door gebruikmaking van vereenvoudigde en gestandardiseerde onderzoeksprotocollen kon voor enkele categorieën klinische vraagstellingen de gemiddelde onderzoeksduur voor MRI zodanig worden bekort dat de kosten per onderzoek beduidend onder die van het CT onderzoek kwamen te liggen, terwijl de diagnostische waarde van MRI op zijn minst gelijkwaardig bleef aan die van $C T$.

$\mathrm{Nu}$ is een dergelijke vereenvoudigde werkwijze zeker niet voor alle vraagstellingen geschikt, maar wanneer men bedenkt dat de ontwikkeling van snellere onderzoeksmethoden bij MRI juist de laatste tijd in de belangstelling staat, lijkt het wel waarschijnlijk dat de gemiddelde onderzoekstijden bij MRI beduidend zullen dalen, en daarmee de apparatuurgebonden kosten. Ook ten opzichte van de klassieke contrastonderzoeken zoals angiografie, caudografie en myelografie is MRI in het voordeel omdat de andere genoemde onderzoeken vaak gebonden zijn aan een opname in het ziekenhuis, met de bijbehorende hoge kosten.

Tegenover deze besparing in apparatuurkosten van MRI 
staat de noodzaak om te investeren in expertise van het bedienend personeel. Wil zowel het diagnostische als het financiële rendement van MRI optimaal worden gerealiseerd, dan is een vakkundige bediening van het allergrootste belang. Dit geldt niet alleen voor de laboranten die het systeem bedienen, maar ook voor de radioloog die het onderzoek superviseert. Om een voorbeeld te geven: bij CT geschiedt de beeldvorming door analyse van één enkele weefselvariabele, namelijk de electronendichtheid. Bij MRI kan men kiezen uit beelden die weefselverschillen weergeven in protonendichtheid, in longitudinale magnetisatietijd $\mathrm{T}_{1}$ en in transversale magnetisatietijd $\mathrm{T}_{2}$. Bij CT is de dikte van de tomografische snede instelbaar en het afbeeldingsvlak slechts in beperkte mate. Bij MRI is er geen beperking in de keuze van snededikte of snedevlak. Bovendien wordt de beeldkwaliteit bij MRI sterk beïnvloed door bijvoorbeeld de keuze van beeldmatrix, beeldomvang en van het type spoel, de uitwendige radioantenne. De winst van MRI wordt alleen verkregen wanneer uit deze overdaad aan keuzemogelijkheden de optimale combinatie wordt geselecteerd. Deze combinatie is afhankelijk van het gebied dat afgebeeld moet worden, en ook van de aard van de afwijking die men verwacht aan te treffen.

Met deze opmerkingen heb ik het belang willen benadrukken van een goed opgeleide en gemotiveerde bemanning van een MRI-systeem. Ontkenning van dit belang kan leiden tot een oppervlakkige routineuze werkwijze waarbij weliswaar de "produktie" indrukwekkend lijkt, maar de mogelijkheden van de apparatuur niet optimaal worden benut. Anderzijds kan een gebrek aan deskundigheid in de juiste keuze van instrumentele parameters leiden tot verspilling van onderzoekstijd. Terloops zij opgemerkt dat zelfs de meest deskundige en toegewijde MRI bemanning in de eerdergenoemde 
problemen kan komen wanneer men noodgedwongen een onderzoek moet verrichten zonder een adequaat geformuleerde klinische vraagstelling.

Ook bij een optimale MRI bezetting, en een optimale communicatie tussen aanvrager en uitvoerder van het onderzoek, is er echter een keerzijde. De invasiviteit; het ongemak en risico van de oudere onderzoeken had een belangrijke drempelwerking. Een cerebraal vaatonderzoek of luchtonderzoek werd vroeger alleen verricht indien er overtuigende klinische verdenkingen waren op het bestaan van een afwijking in de hersenen. Een caudografisch contrastonderzoek van de lumbale zenuwwortels werd pas verricht wanneer op grond van de klinische bevindingen en het klinisch beloop een hernia operatie in het verschiet lag. Het doel van het röntgenonderzoek in dit geval was alleen om de hernia nauwkeurig te lokaliseren in verband met de operatie en om met zekerheid vast te stellen dat de zenuwbeknelling die leidde tot de uitstralende pijnklachten niet een andere oorzaak had, bijvoorbeeld een tumor. Het wegvallen van de drempel van onaangename, soms gevaarlijke onderzoekingen opent de deur voor een volumetoename. Natuurlijk is dit op de eerste plaats een zegen omdat aandoeningen eerder en in een beter behandelbare fase kunnen worden opgespoord. Een nadeel is evenwel dat de indicatiestelling wordt verruimd. Zo is het al heel gewoon dat een patiënt met hardnekkige klachten zoals hoofdpijn of duizeligheid zonder verdere verschijnselen of bevindingen bij lichamelijk onderzoek, wordt verwezen voor CT onderzoek alhoewel bekend is dat de kans op het vinden van een significante afwijking in een dergelijke situatie vrijwel nihil is. In het Amerikaanse jargon is hiervoor de term "CT-negative headache" bedacht. Een ander voorbeeld is dat van de patiënt die al een tijd last heeft van rugpijn zonder uitstraling naar de benen of andere verschijnselen 
van beknelling van de zenuwwortel. Hij heeft op de televisie een programma gezien waarin de beeldvormende eigenschappen van MRI breed worden uitgemeten, en heeft bovendien in de krant gelezen dat er in een naburig ziekenhuis onlangs een dergelijke scanner is geplaatst. Omdat hij zich zorgen maakt over een mogelijke hernia, doet hij een beroep op zijn behandelende arts om een dergelijk onderzoek te kunnen ondergaan.

Het is de weinig dankbare taak van de radioloog om, zonder de indruk van betutteling te wekken, toch regulerend op te treden. Enkele jaren geleden wees op deze plaats van Engelshoven op het belang van een intensief, liefst dagelijks overleg tussen radiodiagnost en klinikus, niet alleen bij de interpretatie van de beelden achteraf, maar ook bij de indicatiestelling en strategiebepaling vooraf. Ik onderschrijf deze opmerkingen van harte.

\section{De blik te scherp}

Ook de winst wat betreft het oplossend vermogen van de nieuwe beeldvormende systemen heeft een keerzijde. Bij de oudere methoden was het vermogen om anatomische veranderingen in de hersenen of in het wervelkanaal te detecteren, zeer beperkt. Alleen betrekkelijk grove veranderingen zoals een hersentumor van enkele centimeters in doorsnee of een grote discushernia in het lumbale wervelkanaal, konden worden waargenomen.

Met behulp van CT en vooral MRI zijn veel meer anatomisch details in beeld te brengen. Helaas zien geen twee mensen er echter van binnen hetzelfde uit. Het wordt dan ook steeds moeilijker om vast te stellen of een enigszins afwijkend anatomisch beeld dat op een MR afbeelding wordt waargenomen berust op een toevallige anatomische variant, een goe- 
daardige speling van de natuur of wellicht een normaal verouderingsverschijnsel, of dat men hier te maken heeft met een afwijking die een verklaring kan vormen voor de klachten van de patiënt.

Men zou kunnen stellen dat in de beeldvormende diagnostiek een nieuw soort ruis aan het ontstaan is: een ruis die niet het gevolg is van de gebrekkige kwaliteit van het beeldvormende systeem, maar die door een overdaad aan anatomische details en irrelevante morfologische veranderingen de diagnostiek kan vertroebelen. Deze diagnostische ruis neemt juist toe naarmate de beeldvorming verbetert.

Ik wil dit graag toelichten aan de hand van enkele voorbeelden. Een onderzoeksgebied waarnaar mijn belangstelling van begin af aan is uitgegaan, is dat van de lumbale discushernia en de beeldvormende diagnostiek hiervan. In de vroege dertiger jaren introduceerden Mixter en Barr het begrip hernia nuclei pulposi als verklaring voor het symptoom van de ischialgie oftewel uitstralende pijnklachten in het been. Bovendien werd het gunstig effect van operatieve ingrepen beschreven bij deze categorie van patiënten bij wie de hardnekkige klachten tot op dat tijdstip onbegrepen waren. Dit concept en de bijbehorende behandelingswijze, werd spoedig algemeen overgenomen, zodat in de decennia daarna de begrippen ischialgie ("ischias") en lumbale discus hernia bijna elkaars synoniem werden. Inmiddels is men hierover wat meer genuanceerd gaan denken, mede omdat met de introduktie van CT op grote schaal bleek dat in een belangrijk percentage van de gevallen geen sprake was van een hernia maar eerder van vernauwing van het lumbale wervelkanaal op basis van aanleg of slijtage. Bovendien heeft men, door schade en schande wijs geworden, herontdekt dat er behalve anatomische compressie van de zenuwwortel, nog vele andere verklaringen kunnen zijn voor rugpijn die uitstraalt in 
het been. Het omgekeerde is echter ook het geval.

Kadaverstudies tonen veelvuldig afwijkingen aan de tussenwervelschijf en ook botwoekeringen veroorzaakt door slijtage in individuen die bij het leven nooit belangrijke rugklachten hadden gehad, in percentages oplopend tot $60 \%$, en vooral bij oudere individuen. Met behulp van caudografische contrastonderzoeken in dit gebied kon Hitselberger deze waarnemingen bevestigen. Bij patiënten die een lumbale contrastinjectie ondergingen vanwege klachten afkomstig van andere gebieden, bleek er in $24 \%$ van de gevallen sprake te zijn van caudografische afwijkingen in de lage rug. Toch hadden deze patiënten geen klachten van dit gebied. Een caudografische kadaverstudie door Hamer leverde $32 \%$ afwijkingen op.

Computertomografie is in staat meer details te detecteren, en een in 1984 gepubliceerde studie van Wiesel van 52 asymptomatische vrijwilligers, liet een hoger percentage afwijkende bevindingen zien: $35 \%$ voor de gehele groep en zelfs $50 \%$ voor de groep ouder dan 40 jaar. Publicatie van deze gegevens bracht nogal wat commotie te weeg; de reacties waren heftig en vaak emotioneel.

Een eigen studie van 100 patiënten die zowel caudografie als CT hadden ondergaan gaf bij 30 patiënten met uitsluitend éénzijdige pijnklachten in 21 gevallen bij caudografie afwijkingen te zien aan de klachtenvrije kant, en bij CT in 23 gevallen. Deze afwijkingen waren wisselend van ernst, maar maakten bij CT een iets meer uitgesproken indruk dan bij caudografie.

Een recent rapport van Johansen laat zien wat de gevolgen zouden kunnen zijn van een al te kritiekloos afgaan op de beelvormende diagnostiek alleen. Er werden vijf gevallen gerapporteerd van patiënten met uitstralende pijn in de been, waarbij het CT onderzoek een lumbale discushernia liet zien. 
In drie van deze gevallen werden de klachten echter veroorzaakt door een tumor in een gebied van het bekken, en in de twee overige door vernauwing van de bloedvaten van de benen. Gelukkig is met behulp van een grondige ondervraging van de patiënt en een gedegen klinisch onderzoek doorgaans wel een onderscheid te maken tussen ischialgie veroorzaakt door lumbale wortelcompressie en pijn in het been door de genoemde andere oorzaken. Indien men evenwel na het noteren van de klacht van ischialgie verder klakkeloos vertrouwt op de beelvormende diagnostiek dan loopt de patiënt het risico te worden geopereerd aan een asymptomatische discusafwijking terwijl de onderliggende oorzaak van klachten onbehandeld blijft.

Het probleem doet zich niet alleen in het lumbale gebied voor: thoracaal zijn met behulp van MRI door Williams bij $15 \%$ van de patiënten asymptomatische hernia's gevonden. In het cervicale gebied zijn door Teresi als toevalsbevinding veelvuldig discushernia's waargenomen bij individuen zonder nekklachten die met MRI werden onderzocht wegens vermeende pathologie van de schildklier. Bij de oudere categorie bezat meer dan de helft een dergelijke asymptomatische discushernia.

Uit eigen onderzoek met gebruik van CT myelografie in het cervicale gebied bleek ons dat bij vele patiënten opvallende radiologische afwijkingen konden worden gezien aan de zijde waar de patiënt geen pijnklachten aangaf. Het gelukte ons wel een klassificatie samen te stellen van radiologische kenmerken die in meer of mindere mate een betrouwbaar verband toonden met het optreden van klinische verschijnselen.

De lijst is nog verder aan te vullen.

In de hersenen treden bij individuen boven de 40 jaar in toenemende mate bij stijgende leeftijd, kleine gebiedjes op 
met veranderde signaalintensiteit op een MRI scan, zogenaamde "unidentified bright objects" of UBO's. Deze worden thans beschouwd als een normaal verouderingsverschijnsel, maar ze zijn echter niet altijd gemakkelijk te onderscheiden van kleine infarctjes, of bij jongere patiënten van demyelisatiehaardjes bij multiple sclerose. Buiten het terrein van de neuroradiologie kunnen wij noemen de bevinding van kleine noduli echografisch vastgesteld in de schildklier van ongeveer een kwart van de normale individuen. In de hypofyse blijken microadenomen te kunnen worden aangetoond bij ongeveer $40 \%$ van de gezonde vrouwen zonder endocrinologische afwijkingen.

Dit korte overzicht geeft aan hoe groot het probleem is waarmee wij ons geconfronteerd zien. In de toekomst zal het misschien wenselijk worden de fabrikanten van beeldvormende apparatuur te verplichten op iedere foto, net als bij een pakje sigaretten, een waarschuwing af te drukken, in dit geval de woorden van Rothman: "Diagnostic studies should confirm surgical decisions, not initiate them."

\section{De oude en de nieuwe neuroradioloog}

Naarmate de neuroradiologische onderzoeksmethoden minder tijdrovend worden, en minder hoge eisen stellen aan catheter- en naaldvaardigheid, wordt het terrein van de neuroradiologie steeds meer toegankelijk en aantrekkelijk voor niet-neuroradiologen.

Voor het overgrote deel gaat het om algemene radiodiagnosten. Deze hebben in Nederland een voortreffelijke opleiding in beeldvormende technieken achter de rug, en de huidige generatie assistenten wordt steeds intensiever geconfronteerd met CT en MRI. Ondanks het steeds gebruikelijker 
worden van het zg. klinische jaar voor de assistent in spe, blijft het klinische aspect een zwakke schakel in de opleiding tot radiodiagnost. De rol van een radiodiagnost zou idealiter die moeten zijn van consulent. De verwijzende klinikus legt een klinische vraagstelling voor aan de radiodiagnost, waarna de meest geschikte diagnostische modaliteit wordt geselecteerd. Bij een techniek als MRI is het wenselijk om de grenzen van het af te beelden gebied zo goed mogelijk te definiëren, en ook een plan te maken van de pulssequenties die zullen worden toegepast om de vraagstelling bondig te beantwoorden. Hiervoor is een dialoog nodig tussen aanvrager en uitvoerder van het onderzoek, waarin vooral klinische gegevens worden uitgewisseld en getaxeerd. $\mathrm{Na}$ de uitvoering van het onderzoek worden de verkregen beelden beschreven en geïnterpreteerd in het kader van de vraagstelling. In deze fase zal ook vaak overleg plaatsvinden met de aanvrager en soms om nadere klinische gegevens worden gevraagd, vooral bij onverwachte of marginale bevindingen. Wanneer de radiodiagnost (en dit geldt niet alleen voor de neuroradioloog) geen voldoende klinische achtergrond heeft, kan hij de rol van consulent niet adequaat vervullen. Overgeleverd aan zijn aanvragers kan hij in het ergste geval alleen plaatjes op bestelling leveren en summiere anatomische beschrijvingen geven van de verkregen beelden. Voor de meer routinematige gevallen lijken de bezwaren van een dergelijke rol niet al te groot, maar een routinematige vraag kan een ingewikkeld antwoord vereisen.

Het probleem wordt des te meer knellend naarmate met de komst van meer moderne beeldvormende apparatuur het volume aan non-invasieve neuroradiologische diagnostiek sterk toeneemt terwijl het aantal gespecialiseerde neuroradiologen steeds meer achterblijft.

Het is dan ook verheugend om te kunnen melden dat er 
besprekingen tussen de Werkgroep voor Neuroradiologie en het Concilium Radiodiagnosticum gaande zijn, met het doel om te komen tot een opleiding van algemene radiodiagnosten in de neuroradiologie. De doelstelling hierbij is niet om academische neuroradiologen af te leveren die zullen worden ingezet in bijvoorbeeld neurochirurgische centra, maar om een gedegen basis te verstrekken voor een radiodiagnost die zal komen te werken in een middelgroot perifeer ziekenhuis. Gedacht wordt aan een zogenaamde fellowship van een jaar na de algemene opleiding. Het spreekt vanzelf dat een dergelijke neuroradiologische basisopleiding een belangrijk klinisch aandeel zal moeten bevatten.

Een tweede groep niet-neuroradiologen die aanspraken lijkt te maken op dit vakgebied wordt gevormd door de clinici zelf: neurologen en neurochirurgen. Vanuit deze hoek is de laatste tijd wel eens voorgesteld om het beheer van MRI scanners over te dragen; de Kernenergiewet vormt immers geen belemmering meer aangezien er geen röntgenstraling aan te pas komt.

Een eerste belangrijk nadeel hiervan betreft de financiën. Over de gevolgen van zelfverwijzing, waarbij de arts die de indicatie stelt voor een bepaald onderzoek dezelfde persoon is als degene die het onderzoek uitvoert en het honorarium declareert, is reeds veel geschreven. Ik volsta dan ook met verwijzing naar de literatuur. Een tweede, meer essentieel medisch nadeel is het volgende. Klinische hypothesen, vermoedens van het bestaan van een bepaald soort pathologie op grond van de bevindingen bij anamnese en algemeen lichamelijk onderzoek, zijn niet onfeilbaar. Indien dit wel het geval was, dan had het technisch hulponderzoek waarvan de beeldvorming een onderdeel vormt niet de hoge vlucht genomen die heden ten dage is bereikt. In sommige gevallen is de klinische verdenking in een bepaalde richting zo sterk en 
de wens om tot een diagnose te komen zo groot, dat de interpretatie van de beeldvormende bevindingen hierdoor kan worden beïnvloed. De overdaad aan anatomische details die in een modern beeldvormend onderzoek aanwezig is, kan dit onderzoek dan veranderen in een soort grabbelton, waaruit iedereen het bewijsstuk kan plukken dat men nodig meent te hebben. De neuroradiologische consulent kan nu op grond van zijn specifieke deskundigheid optreden, soms als "advocaat van de duivel", in ieder geval interpreterend en relativerend.

Met het voorafgaande hoop ik duidelijk te hebben gemaakt dat alhoewel in een snel veranderende beeldvormende wereld het terrein van de neuroradiologie ogenschijnlijk toegankelijker is geworden voor buitenstaanders, de gespecialiseerde neuroradioloog een centrale rol blijft vervullen in het diagnostisch systeem. Zowel bij de selectie en planning van het onderzoek als bij de evaluatie van de bevindingen is zijn bijdrage essentieel. Deze bijdrage kan hij alleen leveren op basis van gedegen kennis van de klinisch-neurologische symptomen en syndromen, de neuroradiologische verschijningsvormen en de verbanden tussen beiden.

Wanneer wij terugblikken op de ontwikkeling van de neuroradiologie, dan is het opvallend dat de belangrijkste innovaties in de radiodiagnostiek voor het eerst zijn toegepast voor de beeldvorming van het zenuwstelsel. Ik noem hierbij oudere methoden zoals angiografie, isotopenscintigrafie en zelfs echografie, meer recente ontwikkelingen zoals computertomografie en magnetische resonantie, en ook positron emissie tomografie. Al deze technieken zijn in eerste instantie op de hersenen gericht geweest, alhoewel in een latere fase het toepassingsgebied werd uitgebreid naar andere organen. De neuroradiologie lijkt dus de rol te hebben vervuld van een 
beeldvormende proeftuin. De unieke problemen van afbeelding binnen de schedel en het wervelkanaal stimuleren het vinden van oplossingen en de groei van nieuwe technieken. Deze functie maakt het werkterrein van de neuroradiologie boeiend voor haar beoefenaren en niet onbelangrijk voor de vooruitgang van de radiodiagnostiek als geheel. 


\section{Dankwoord}

Aan het slot van mijn betoog gekomen rest mij de aangename taak een woord van dank uit te spreken.

Aan het Bestuur van de Stichting St. Annadal, het College van Bestuur van de Rijksuniversiteit Limburg, en de Raad van Bestuur van het Academisch Ziekenhuis Maastricht voor de erkenning van het belang van mijn vakgebied, de Neuroradiologie, die uit deze benoeming spreekt.

Aan de vrienden en medewerkers in het Academisch Ziekenhuis Groningen. Bij hen en met hen heb ik mijn kennis en vaardigheden kunnen ontwikkelen. De ervaringen samen met hen opgedaan vormen een onuitwisbare herinnering.

Aan mij leermeesters Droogleever Fortuyn en Minderhoud in de neurologie, Beks in de neurochirurgie, Pols in de psychiatrie, Blickman en Thijn in de radiodiagnostiek. De bijzondere rol van Lourens Penning heb ik reeds aangehaald.

Aan de staf en assistenten van de vakgroep radiodiagnostiek van het Academisch Ziekenhuis Maastricht. Het enthousiasme waarmee $\mathrm{zij}$ mij verwelkomden en in hun midden opnamen, was voor mij een stimulerend begin. Ook het overige personeel van de vakgroep wil ik bedanken, niet in de laatste plaats voor hun geduld met een soms wellicht wat ongeduldige nieuweling. In mijn betoog heb ik het belang willen benadrukken van inzet en deskundigheid bij degenen die moderne beeldvormende apparatuur bedienen. Ik prijs mijzelf gelukkig om in onze laborantengroep deze eigenschappen in royale mate aan te trefffen.

Aan mijn vader die deze dag niet heeft mogen meemaken. Aan mijn moeder. $\mathrm{Zij}$ wist het belang van deze stap voor mij te onderkennen, en te accepteren. Vanaf deze plaats wil ik haar mijn dank betuigen.

Aan Jelly, en ook Maaike, Dirk, Adriaan en Judith. Na acht maanden gescheiden huishouding volgde een voor jullie volledige ontworteling. $\mathrm{Ik}$ ben verheugd dat nieuwe wortels 
zich voorspoedig blijken te kunnen ontwikkelen. De wijze waarop jullie deze periode hebben doorstaan verdient bewondering.

Ik heb gezegd, en dank $u$ voor uw aandacht. 


\section{Literatuur}

1. Ziedses des Plantes BG.

The value of magnetic resonance imaging (MRI) in a general hospital. Proefschrift, Utrecht, (1992).

2. Van Engelshoven JMA.

Onderweg naar meer zekerheid.

Inaugurale rede, Maastricht (1987).

3. McRae DL.

Asymptomatic intervertebral disc protrusions.

Act. Rad. 46:9-27; (1956).

4. Hitselberger WE, Witten RM.

Abnormal myelograms in asymptomatic patients.

J. Neurosurg. 28:204-206 (1968)

5. Hamer J.

Asymptomatic protrusions of lumbar intervertebral disc (postmortem myelography).

Modern aspects of Neurosurgery, 3:14-17; (1971).

6. Wiesel SW, et al.

A study of computer-assisted tomography.

I. The incidence of positive CAT scans in an asymptomatic group of patients.

Spine, 9:549-556; (1984).

7. Wilmink JT.

CT Morphology of intrathecal lumbosacral nerve-root compression.

AJNR 10:233-248; (1989). 
8. Johansen JG, et al.

Extraspinal pathology and incidental disc herniation in patients with sciatica.

Spine, 13:437-439; (1988).

9. Williams MP, et al.

Significance of thoracic disc herniation demonstrated by

MR imaging.

Journal of Computed Assisted Tomography 13:211-214; (1989).

10. Teresi LM, et al.

Asymptomatic degenerative disk and disease and spondylosis of the cervical spine: MR imaging.

Radiology 164:83-88; (1987).

11. Penning L., et al.

CT Myelographic findings in degenerative disorders of the cervical spine: clinical significance.

AJNR 7:119-127: (1986).

12. Forrest JV.

Generalists vs specialists: time to decide.

AJR 156:1277-1278; (1991).

13. Thrall $\mathrm{JH}$, Wittenberg J.

Radiology summit 1990: specialization in radiology trends, implications, and recommendations.

AJR 156:1273-1276; (1991).

14. Hillman BJ.

Whose turf is imaging? Independent practice, academics, and research.

AJR 156:443-447; (1991). 